\title{
Effect of Statins and Aerobic Physical Exercise on Liver Function in Dyslipidemic Rats - Morphometric Study
}

\author{
Efecto de las Estatinas y Ejercicio Físico Aeróbico sobre la Función \\ Hepática en Ratas Dislipémicas - Estudio Morfométrico
}

\begin{abstract}
Marilita Falângola Accioly*; Dorotéia Rossi Silva Souza**; Susimary Aparecida Trevizan Padulla***; José Carlos Silva

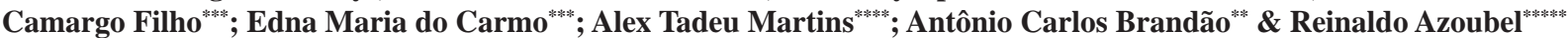

ACCIOLY, M. F.; SOUZA, D. R. S.; PADUlla, S. A. T.; CAMARGO FILHO, J. C. S.; DO CARMO, E. M. ; MARTINS, A. T.; BRANDÃO,A. C. \& AZOUBEL, R. Effect of Statins and Aerobic Physical Exercise on Liver Function in Dyslipidemic Rats - Morphometric Study. Int. J. Morphol., 31(4):1309-1316, 2013.

SUMMARY: The present study was carried out to evaluate the effect of statins associated with physical exercise (PE) in liver cells in dyslipidemic rats through cariometry. The animals were divided into six groups: animals subjected to a hypercholesterolemic diet (HD), simvastatin, with (G1) and without (G2) physical exercise (PE); HD submitted (G3) or not (G4) to PE, and commercial food diet (F) with (G5) and without (G6) PE. Histological analysis of the liver was performed by staining the slides with hematoxylin and eosin. The cariometric study included measuring the major and minor diameters of the hepatocytes nuclei. The Shapiro-Wilk test was also performed. To determine the differences among the groups, the Kruskal-Wallis Test with Dunn's post-test were conducted. The significance level was set at 5\%. No difference was found in the hepatocytes nuclei between G5 and G6. When these groups were related with G3 and G4, reduced nuclei were observed. There was no difference between G1 and G6. The comparison between G6 and G2 showed that the nuclei in G2 were smaller. No difference was detected between G5 and G1. Changes were observed in the nuclei shape in G2 in comparison to G1. Considering G2 and G3, a decrease in the size of nuclei was observed in G3. On the other hand, G2 showed changes in shape in the comparative analysis with G4. The size and shape of G1 nuclei were larger than G3 as well as changes in shape were observed when compared to G4. G4 showed smaller nuclei than G3. Therefore, F, associated or not with the practice of PE, does not alter the size and shape of the hepatocytes nuclei; HD combined with sedentarism influences changes in the morphometric parameters of hepatocytes; and the association of simvastatin and PE seems to protect the hepatocytes nuclei with regard to HD.

KEY WORDS: Simvastatin; Exercise; Diet; Cariometry.

\section{INTRODUCTION}

Dyslipidemia is characterized by disturbances in the levels of circulating lipids with various clinical manifestations. Its therapy often includes adequate food, regular practice of physical exercise associated or not to drug treatment. Statins are widely prescribed and are effective in the treatment of dyslipidemia and in the control of risks of atherosclerotic vascular diseases, not to mention their various benefits and pleiotropic effects. Their basic mechanism of action is the inhibition of the enzyme HMG-CoA reductase (hydroxymethylglutaryl coenzyme A), which regulate the production of intracellular and liver cholesterol. This enzyme catalyzes the conversion of HMG-CoA derived from acetate to mevalonic acid, which leads to the synthesis of cholesterol (Beltowski et al., 2009).
Although generally well tolerated by most patients, statins require attention regarding their side effects, namely myopathy and hepatotoxicity. Although severe, hepatotoxicity is rare (3\%) and dose-related (Paragh \& Fülöp, 2009). The mechanisms which favor the development of hepatotoxicity due to statins are still little known. The druginduced liver injury can be either hepatocellular, which will result in increased Aspartate Aminotransferase (AST) and Alanine Aminotransferase (ALT); or cholestatic, which will lead to increased bilirubin. Generally, this increase is asymptomatic, transient and is resolved after discontinuation of the drug (Tavintharan et al., 2007; Armitage, 2007).

In most cases, such biochemical finding is not related

\footnotetext{
Professor, Department of Applied Physical Therapy, Federal University of Triângulo Mineiro (UFTM), Uberaba/MG, Brazil.

** Professor, Faculty of Medicine of São José do Rio Preto (FAMERP), São José do Rio Preto/SP, Brazil.

**** Professor, Department of Physical Therapy, FCT/UNESP, Campus de Presidente Prudente/SP, Brazil.

**** Professor/Orienter of Postgraduate Program of Dental Sciences at University Center of Educacional Fundation of Barretos (UNIFEB), Barretos/SP, Brazil.

${ }^{* * * * * *}$ Professor/Orienter of Postgraduate Program of Health Sciences at Faculty of Medicine of São José do Rio Preto (FAMERP), São José do Rio Preto/SP, Brazil.
} 
ACCIOLY, M. F.; SOUZA, D. R. S.; PADULla, S. A. T.; CAMARgO FILHO, J. C. S.; DO CARMO, E. M. ; MARTINS, A. T.; BRANDÃO, A. C. \& AZOUBEL, R. Effect of Statins and Aerobic Physical Exercise on Liver Function in Dyslipidemic Rats - Morphometric Study. Int. J. Morphol., 31(4):1309-1316, 2013.

with any histopathological changes and therefore can not meet the criteria for a true indicator of liver injury (Argo et al., 2008).

Another way to detect liver damage is by a morphometric evaluation of the liver tissue. Morphometric studies include the analysis of the shape and its relation to the size. It is a supporting method for the diagnosis of cell alterations which help physiological and pathological analysis to establish quantitative correlations between the structure and function of organs, including the liver (Sala et al., 1992)

A diet rich in fat and dyslipidemia also promote liver and hepatocytes damage. The most common disorder is hepatic steatosis. In this case, predominant accumulation of triglycerides (TG) is commonly found in histology exams of the liver, often associated with an increase of cholesterol, phospholipids and free fatty acids in liver content. Any imbalance between hepatic TG rates can lead to the accumulation of lipids in the liver (Ludwig et al., 1997).

The regular practice of aerobic physical exercise causes a reduction in TG levels, a notable increase in cholesterol fraction of high density lipoprotein (HDL-c), and beneficial changes in the chemical composition of its sub-fractions, with increased HDL2-c as well as decreased HDL3-c. (do Valle et al., 2010). Moreover, it is associated with increased activity of the lipoprotein lipase and the lecithin-cholesterol acyltransferase enzymes as well as with reduced activity of cholesteryl ester transfer protein. Therefore, physical exercise has an effect on the lipoprotein metabolism, influencing the reverse cholesterol transport and the metabolism of TG-rich lipoproteins (Kelley \& Kelley, 2006). On the other hand, levels of the low-density lipoprotein cholesterol fraction (LDLc) show resistant to physical training, which seems, however, to reduce the level of oxidized LDL, leading to lower risk of atherosclerosis (Sasaki \& Santos, 2006).

So, the objective of this study was to evaluate the effect of statins associated with physical exercise in liver cells in dyslipidemic rats through cariometry.

\section{MATERIAL AND METHOD}

This study followed all ethical procedures required, with the approval of the Ethics Committee on Animal Experiments of the Faculty of Medicine of São José do Rio Preto- CEEA-FAMERP (Case No. 5363/2005).
Thirty male Wistar rats (Rattus norvegicus) were selected at random, with an average weight of $272.9 \pm 26.68$ $\mathrm{g}$. They were kept in plastic cages in a vivarium, with average temperature of $22 \pm 2$ ?C and humidity of $50 \pm 10 \%$. Additionally, a light-dark cycle of 12 hours, with start of the light cycle at 07:00 am, was introduced. Food and water were provided ad libitum and changed daily. The animals were randomly divided into six groups of five animals according to the type of diet, administration of lipid-lowering medication, performed by gavage, and practice of physical exercise, as identified below:

- Group 1 (G1) - hypercholesterolemic diet during 90 days with administration of lipid-lowering drug (simvastatin) and physical exercise on treadmill, both for 8 weeks.

- Group 2 (G2) - hypercholesterolemic diet during 90 days with administration of lipid-lowering drug (simvastatin) for 8 weeks and sedentarism.

- Group 3 (G3) - hypercholesterolemic diet during 90 days and physical exercise on treadmill for 8 weeks.

- Group 4 (G4) - hypercholesterolemic diet during 90 days and sedentarism.

- Group 5 (G5) - commercial food diet (Purina) during 90 days, with physical exercise on treadmill for 8 weeks.

- Group 6 (G6) - commercial food diet (Purina) during 90 days and sedentarism.

The hypercholesterolemic diet was based on AIN-93 plus starch $(290 \mathrm{~g} / \mathrm{kg})$, dextrinized starch $(155 \mathrm{~g} / \mathrm{kg})$, commercial casein $(175 \mathrm{~g} / \mathrm{kg})$, sucrose $(100 \mathrm{~g} / \mathrm{kg})$, cellulose $(50 \mathrm{~g} / \mathrm{kg})$, coconut fat $(120 \mathrm{~g} / \mathrm{kg})$, soybean oil $(47.5 \mathrm{~g} / \mathrm{kg})$, cholesterol $(12.5 \mathrm{~g} / \mathrm{kg})$, mineral mixture $(35 \mathrm{~g} / \mathrm{kg})$, vitamin $\operatorname{mix}(10 \mathrm{~g} / \mathrm{kg})$, L-cystin $(1.8 \mathrm{~g} / \mathrm{kg})$, choline bitartrate $(2.5 \mathrm{~g} /$ $\mathrm{kg}$ ) and tert-Butilhdroquinone $(0.014 \mathrm{~g} / \mathrm{kg}$ ) (Reeves et al., 1993).

After selecting the animals, they had to fast for 12 hours and then blood samples were collected by cardiac puncture in order to analyse their lipid profile, including total serum cholesterol level (TC), HDLc and TG. These were defined as baseline parameters (Time Zero - T0). New blood samples were collected for the lipid profile analysis after 30 days of administration of hypercholesterolemic diet, being defined as final parameters (Time 1 - T1). For the collection of blood samples, 12 hours of fasting and 24 hours of rest were observed. The evaluation in T1 was performed in order to confirm changes in the lipid profile after 30 days of hypercholesterolemic diet. 
The TG and TC serum levels were determined by enzymatic colorimetric methods, by direct dose, using a set of laboratory testing equipment for Cobas Mira S. The difference between TC and HDLc serum levels was regarded as cholesterol fraction not present in high-density lipoprotein (non-HDL) (Bucolo \& David, 1973).

The drug dosage was calculated by allometric extrapolation (Pachaly \& Brito, 2001) which is based on the metabolic rate of the animal. Due to the growth and change of body weight of the animals, the drug dosage was recalculated weekly, with the initial dose ranging from 0.31 to $0.53 \mathrm{mg}$.

The training program was conducted on a treadmill for small animals, keeping the speed at $9.75 \mathrm{~m} / \mathrm{min}$, for a total of $585 \mathrm{~m}$ in every 60 -minute session - featuring lowintensity effort. The experimental protocol of exercise included two phases: an adaptation phase - with daily walking sessions on a treadmill with progressive duration throughout the first ten days; and a training phase - with daily walking sessions of $60 \mathrm{~min}$, five days a week during eight weeks (Padulla et al., 2009).

After the training period, the animals were chemically euthanized. Their liver was removed by surgical procedure. Liver samples were frozen by immersion in n-hexane, cooled to $-70^{\circ} \mathrm{C}$ with liquid nitrogen-using the method for freezing unfixed tissue- and stored in a nitrogen gas cylinder. The material was sectioned using semi-serial cuts of $8 \mathrm{~mm}$, obtaining three $50 \mathrm{~mm}$-cuts each by means of a microtome cryostat Microm HM $505 \mathrm{E},-20^{\circ} \mathrm{C}$. Histological analysis was performed by staining the material with hematoxylin and eosin (HE) (Accioly et al., 2012).

The cariometric study was conducted through measurement of the major and minor diameters of the hepatocytes nuclei by means of a Hund Wetzlar H500 optical microscope (Helmut Hund GmbH, Germany), with an immersion objective (100-fold increase) equipped with a Leitz Wetzlar light camera (Germany). For each animal, images of 50 hepatocyte nuclei were captured and these were measured by means of a software (Image Pro Plus 6.0.). So, 250 nuclei were measured by each study group, a total of 1,500 for the experiment.

The values of the diameters obtained were entered into an Excel spreadsheet and the following nuclear parameters were obtained throughmathematical calculations: major diameter, minor diameter, medium diameter ((M=D.d)1/2), major diameter / minor diameter ratio (D/d), perimeter $(\mathrm{P}=(\pi / 2) \times[1.5 \mathrm{x}(\mathrm{D}+\mathrm{d})-\mathrm{M}])$, area $(\mathrm{A}=\pi / 4 \mathrm{x}$ $\mathrm{M} 2)$, volume ( $\mathrm{V}=\pi / 6 \times \mathrm{M} 3)$, volume / area ratio $(2 / 3 \times \mathrm{M})$ reflecting the size of nuclei, eccentricity $(E=[D+d) 1 / 2 \times D$
- d1/2)]/D), coefficient of form ( $F=4 \times \pi \times A / P 2)$ and the contour index (I=P/(A) 1/2) characterizing the shape of nuclei (Sala et al., 1992).

Prior to the analysis of the data, the distribution of all variables was tested by the Shapiro-Wilk normality test. Although the data were non-parametric, a descriptive analysis with mean and standard deviations was chosen in order to facilitate comparison with other studies. In order to determine the differences among the groups, a KruskalWallis Test with Dunn's post-test were used, in accordance with the non-parametric data. The level of significance was set at 5\% and the Stata 12 software was used in the analysis.

\section{RESULTS}

Figure 1 shows the mean values and standard deviations for levels of TC, HDLc, non- HDLc, TG, before undergoing a hypercholesterolemic diet (Time Zero - T0) and one month after its administration (Time 1 - T1). A significant increase in TC levels (from $90.5 \pm 25.8$ to 119.8 $\pm 31.6 \mathrm{mg} / \mathrm{dL}, \mathrm{p}=0.0001$ ) and non- HDLc (from 53.0 \pm 26.0 to $99.6 \pm 29.4 \mathrm{mg} / \mathrm{dL}, \mathrm{p}=0.0001$ ) and a significant reduction in the levels of HDLc (from 37.6 \pm 8.4 to $20.1 \pm 5.7 \mathrm{mg} / \mathrm{dL}$, p $=0.0001$ ) were observed after intake of hypercholesterolemic diet. There was no significant variation in TG levels compared the periods $\mathrm{T} 0$ and $\mathrm{T} 1$.

For the cariometric comparative analysis of the results, the nuclear size and shape of the hepatocytes of the animals of group 5 submitted to commercial food diet and physical exercise were considered as standard normal (Table I).

No significant difference was observed in the nuclei of hepatocytes of animals on commercial food diet, and submitted or not to physical exercise (G5 and G6, respectively). However, when relating groups 5 and 6 with those which followed a hypercholesterolemic diet and practiced physical exercise (G3) or not (G4), a reduction in nuclei in both size and shape was observed (Tables I and II). There was no difference in the size and shape of nuclei among groups which were on a commercial food diet and practiced no physical activity (G6) and those groups submitted to a hypercholesterolemic diet, simvastatin and physical exercise (G1). However, the comparison between G6 and G2 (hypercholesterolemic diet, simvastatin and sedentarism) showed that the nuclei in G2 were smaller and had no changes in shape. The comparison between the animals in group 5 (commercial food diet and physical exercise) with those treated with hypercholesterolemic diet, simvastatin and physical exercise (G1) showed no significant differences. 


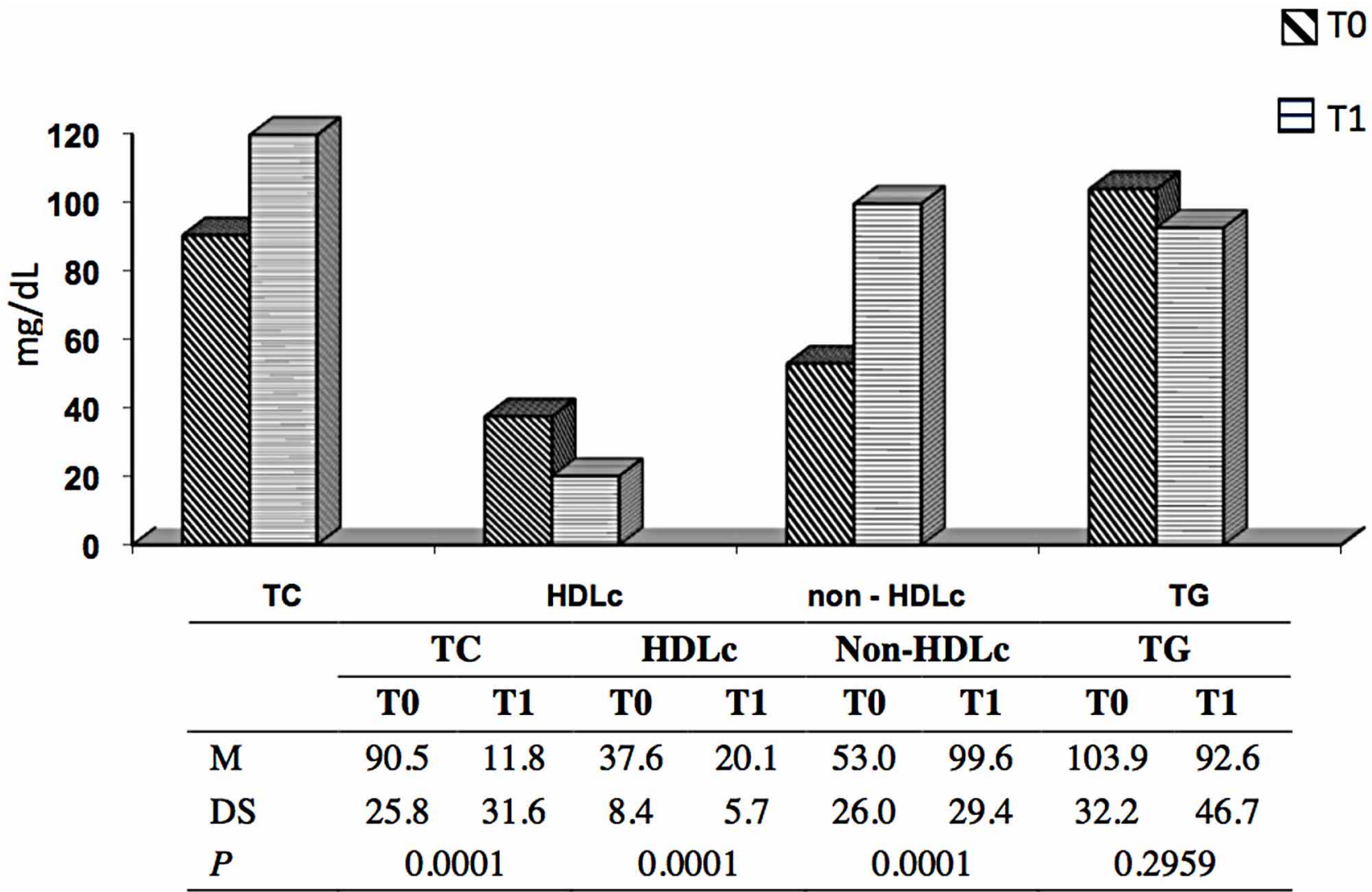

Fig. 1. Distribution of mean values (M) and standard deviation (SD) for total cholesterol (TC), fraction of high density lipoprotein cholesterol (HDL-c); fraction of non-HDL cholesterol (non-HDL-c) and triglycerides (TG) in animals before being submitted to a hypercholesterolemic diet (Time Zero - T0) and after 1 month of diet (Time 1 - T1). p = level of significance.

Table I. Distribution of mean values (M) and standard deviation (SD) for variables: major diameter (DM), minor diameter (dm), medium diameter (medium d), major and minor diameter ratio (D/d ratio), Volume, Area, Perimeter, Volume Area ratio (V/A ratio), Eccentricity, Coefficient of Form (Coeff. Form) and Contour Index (Contour I.) of hepatocyte nuclei of Wistar rats.

\begin{tabular}{lcccccc}
\hline & G1 & G2 & G3 & G4 & G5 & G6 \\
\cline { 2 - 7 } Variable & D+S+EX (A) & D+S+SD (B) & D+EX (C) & D+SD (D) & F+Ex (E) & F+SD (F) \\
& M \pm SD & M \pm SD & M \pm SD & M \pm SD & M \pm SD & M \pm SD \\
\hline DM & $6.79 \pm 1.36$ & $6.68 \pm 0.09$ & $6.20 \pm 1.15$ & $7.13 \pm 1.45$ & $7.26 \pm 0.10$ & $7.07 \pm 0.86$ \\
dm & $4.55 \pm 1.34$ & $4.08 \pm 0.07$ & $3.85 \pm 0.93$ & $4.16 \pm 1.08$ & $4.67 \pm 0.07$ & $4.53 \pm 0.07$ \\
medium d & $5.51 \pm 1.22$ & $5.17 \pm 0.07$ & $4.86 \pm 0.90$ & $5.40 \pm 1.07$ & $5.78 \pm 0.07$ & $5.62 \pm 0.07$ \\
D/d ratio & $1.58 \pm 0.45$ & $1.76 \pm 0.03$ & $1.67 \pm 0.41$ & $1.79 \pm 0.47$ & $1.63 \pm 0.03$ & $1.62 \pm 0.02$ \\
Volume & $101.53 \pm 73.32$ & $83.91 \pm 3.41$ & $66.59 \pm 40.94$ & $93.12 \pm 62.62$ & $115.05 \pm 4.79$ & $105.18 \pm 3.99$ \\
Area & $25.10 \pm 11.42$ & $22.13 \pm 0.61$ & $19.19 \pm 7.37$ & $23.87 \pm 9.96$ & $27.41 \pm 0.74$ & $25.92 \pm 0.65$ \\
Perimeter & $18.06 \pm 3.74$ & $17.25 \pm 0.23$ & $16.07 \pm 2.85$ & $18.12 \pm 3.44$ & $19.07 \pm 0.24$ & $18.51 \pm 0.22$ \\
V/A ratio & $3.67 \pm 0.81$ & $3.45 \pm 0.04$ & $3.24 \pm 0.60$ & $3.60 \pm 0.71$ & $3.85 \pm 0.05$ & $3.75 \pm 0.04$ \\
Eccentricity & $0.70 \pm 0.016$ & $0.75 \pm 0.009$ & $0.75 \pm 0.12$ & $0.77 \pm 0.13$ & $0.71 \pm 0.01$ & $0.73 \pm 0.008$ \\
Coeff. form & $0.92 \pm 0.008$ & $0.88 \pm 0.006$ & $0.90 \pm 0.07$ & $0.88 \pm 0.08$ & $0.91 \pm 0.005$ & $0.91 \pm 0.004$ \\
Contour I. & $3.70 \pm 0.19$ & $3.78 \pm 0.01$ & $3.73 \pm 0.18$ & $3.79 \pm 0.20$ & $3.73 \pm 0.01$ & $3.72 \pm 0.01$ \\
\hline
\end{tabular}

$\mathrm{G} 1=$ Group 1. D + S + EX (A) = hypercholesterolemic diet, simvastatin, exercise. G2 = Group 2. D + S + SD (B) = hypercholesterolemic diet, simvastatin, sedentarism. G3 = Group 3. D + EX (C) = hypercholesterolemic diet and exercise. G4 = Group 4. D + SD (D) = hypercholesterolemic diet and sedentarism. G5 = Group 5. F + EX (E) = commercial food diet and exercise. G6 = Group 6. F+ SD $(F)=$ commercial food diet and sedentarism. 
ACCIOLY, M. F.; SOUZA, D. R. S.; PADULla, S. A. T.; CAMARGO FILHO, J. C. S.; DO CARMO, E. M. ; MARTINS, A. T.; BRANDÃO, A. C. \& AZOUBEL, R. Effect of Statins and Aerobic Physical Exercise on Liver Function in Dyslipidemic Rats - Morphometric Study. Int. J. Morphol., 31(4):1309-1316, 2013.

Table II. Level of significance for the variables: major diameter (DM), minor diameter (dm), medium diameter (medium d), major and minor diameter ratio (D/d ratio), Volume, Area, Perimeter, Volume Area ratio (V/A ratio), Eccentricity, Coefficient of form (Coeff. Form) and Contour Index (Contour I.) of hepatocyte nuclei of Wistar rats.

\begin{tabular}{|c|c|c|c|c|c|c|c|c|c|c|c|c|c|c|c|}
\hline \multirow{2}{*}{ Variable } & \multicolumn{15}{|c|}{ p } \\
\hline & $\mathbf{A x B}$ & AxC & AxD & $\mathbf{A x E}$ & $\mathbf{A x F}$ & BxC & BxD & BxE & BxF & CxD & $\mathrm{CxE}$ & $\mathbf{C x F}$ & DxE & DxF & ExF \\
\hline DM & 0.28 & $<0.05$ & $<0.05$ & 5 & 0.06 & 25 & 4 & 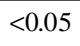 & 5 & $<0.05$ & 5 & 0.05 & 0 & 0.82 & 0.29 \\
\hline $\mathrm{dm}$ & $<0.05$ & $<0.05$ & $<0.05$ & 0.09 & 0.38 & $<0.05$ & 0.73 & $<0.05$ & $<0.05$ & $<0.05$ & $<0.05$ & $<0.05$ & $<0.05$ & $<0.05$ & 0.15 \\
\hline Medium d & 0.07 & $<0.05$ & 0.32 & 0.07 & 0.08 & $<0.05$ & 0.09 & $<0.05$ & $<0.05$ & $<0.05$ & $<0.05$ & $<0.05$ & $<0.05$ & $<0.05$ & 0.19 \\
\hline $\mathrm{D} / \mathrm{d}$ ratio & $<0.05$ & $<0.05$ & $<0.05$ & 0.17 & 0.06 & 0.65 & $<0.05$ & 0.08 & 0.07 & $<0.05$ & $<0.05$ & 0.10 & $<0.05$ & $<0.05$ & 0.17 \\
\hline Volume & 0.07 & $<0.05$ & 0.32 & 0.06 & 0.08 & $<0.05$ & 0.09 & $<0.05$ & $<0.05$ & $<0.05$ & $<0.05$ & $<0.05$ & $<0.05$ & $<0.05$ & 0.19 \\
\hline Area & 0.07 & $<0.05$ & 0.32 & 0.06 & 0.08 & $<0.05$ & 0.09 & $<0.05$ & $<0.05$ & $<0.05$ & $<0.05$ & $<0.05$ & $<0.05$ & $<0.05$ & 0.19 \\
\hline Perimeter & 0.09 & $<0.05$ & 0.76 & 0.09 & 0.08 & $<0.05$ & $<0.05$ & $<0.05$ & $<0.05$ & $<0.05$ & $<0.05$ & $<0.05$ & $<0.05$ & 0.11 & 0.18 \\
\hline V/A ratio & 0.08 & $<0.05$ & 0.32 & 0.07 & 0.08 & $<0.05$ & 0.09 & $<0.05$ & $<0.05$ & $<0.05$ & $<0.05$ & $<0.05$ & $<0.05$ & $<0.05$ & 0.19 \\
\hline Eccentricity & $<0.05$ & $<0.05$ & $<0.05$ & 0.14 & 0.08 & 0.60 & 0.05 & 0.07 & 0.06 & $<0.05$ & $<0.05$ & 0.11 & $<0.05$ & $<0.05$ & 0.19 \\
\hline Coeff. form & $<0.05$ & $<0.05$ & $<0.05$ & 0.17 & 0.09 & 0.65 & $<0.05$ & 0.08 & 0.07 & $<0.05$ & $<0.05$ & 0.10 & $<0.05$ & $<0.05$ & 0.17 \\
\hline Contour I & $<0.05$ & $<0.05$ & $<0.05$ & 0.17 & 0.06 & 0.65 & $<0.05$ & 0.07 & 0.07 & $<0.05$ & $<0.05$ & 0.10 & $<0.05$ & $<0.05$ & 0.17 \\
\hline
\end{tabular}

$\mathrm{P}=$ level of significance. $\mathrm{A}=$ hypercholesterolemic diet, simvastatin, physical exercise. $\mathrm{B}=$ hypercholesterolemic diet, simvastatin, sedentarism. $\mathrm{C}=$ hypercholesterolemic diet and physical exercise. $\mathrm{D}=$ hypercholesterolemic diet and sedentarism. $\mathrm{E}=$ commercial food diet and physical exercise. $\mathrm{F}=$ commercial food diet and sedentarism.

On the other hand, the hepatocytes nuclei of animals which received the same treatment and remained sedentary (G2) were significantly smaller, and the shape of which remained unchanged (Tables I and II).

Changes were observed in the shape of the nuclei: they were longer in those animals submitted to a hypercholesterolemic diet, simvastatin and sedentarism (G2) compared to those with the same treatment, but submitted to physical exercise (G1). When comparing group (G2) with that group with hypercholesterolemic diet and physical exercise (G3), G3 showed a significant reduction in the size of nuclei, and yet its shape remained unchanged. On other hand, G2 showed changes primarily in the shape of the nuclei in the comparative analysis with G4 (hypercholesterolemic diet and sedentarism) (Tables I and II).

Animals treated with hypercholesterolemic diet, simvastatin and physical exercise (G1) had the size and shape of nuclei significantly larger than those with the same diet and submitted to physical exercise (G3). When compared to G4 (hypercholesterolemic diet and sedentarism), G3 showed nuclei with major diameter reduced and minor diameter increased, as well as changes in their shape (Tables I and II).

The group with hypercholesterolemic diet and physical exercise (G4) showed hepatocytes nuclei smaller in size and shape when compared to those submitted to the same diet, but remained sedentary (G3) (Tables I and II).

\section{DISCUSSION}

The hypercholesterolemic diet used in this study was effective as it induced dyslipidemia in Wistar rats, one month after its start. It produced a significant increase in the levels of TC, HDLc fraction and non-significant reduction of HDLc. However, there are references showing animals, including rodents, with hyper responsiveness to hypercholesterolemic diet, which support the use of cholic acid to induce hyperlipidemia and atherosclerosis in such species (Joris et al., 1983)

On the other hand, there are also reports of animal models, including rats, which responded to such diet. Matos et al., (2005) tested four diet models in Fischer female rats during eight weeks, including a high oil content diet with high calorific value, a fibre-rich diet with low-calorific value, a high protein and micronutrients diet, and even an oil and fibre-rich diet, with low calorific value similar to the control group. A significant increase in the levels of TC and significant reduction in HDLc fraction was observed. Concordant results were also observed by Bernardes et al. (2004), when considering the effects of high fat diet and swimming training in Wistar rats.

Morphometric evaluations, including cariometry, have enabled detection of morphological changes that occur in physiopathological conditions such as in experimental 
ACCIOLY, M. F.; SOUZA, D. R. S.; PADULla, S. A. T.; CAMARgO FILHO, J. C. S.; DO CARMO, E. M. ; MARTINS, A. T.; BRANDÃO, A. C. \& AZOUBEL, R. Effect of Statins and Aerobic Physical Exercise on Liver Function in Dyslipidemic Rats - Morphometric Study. Int. J. Morphol., 31(4):1309-1316, 2013.

studies (Sala et al., 1992). In this study, the cariometric analysis of hepatocyte nuclei showed the effect of the hypercholesterolemic diet, which induced reduction in size and change in shape of hepatocytes in experimental dyslipidemia model with or without aerobic exercise. In fact, animals given a fat-rich diet showed accumulation of lipid in the liver, which caused damage of hepatocytes and consequently loss of sinusoids, significant reduction of density of hepatocytes of sinusoids and steatosis, increased body weight as well as changes in levels of plasma lipoproteins (Neves et al., 2006, 2006b).

This study highlights the combination of simvastatin and physical exercise in relation to dyslipidemia. Admittedly physical inactivity is associated with excess of TG, a risk factor for atherosclerosis, hepatic steatosis, diabetes and obesity (Pederson, 2009; Lira et al., 2010). On the other hand, moderate physical training can prevent the accumulation of fat in the liver by reducing the input of lipids in the liver, due to increased hepatic oxidation and the increased incorporation of TG in very low density lipoproteins (VLDL) (Magkos, 2010). Therefore, regular physical activity is inversely associated with hepatic steatosis, independent of age, sex and body mass index, favouring the reduction of fat in the liver and intrahepatic TG (Kay \& Fiatarone Singh, 2006; Ross et al., 2000).

The relationship between high aerobic capacity and lower content of intrahepatic TG is reported in animal model. In this case, there is an increased ability to oxidize fatty acid and decreased lipogenic profile. It is possible that intrahepatic, biochemical and molecular mechanisms associated with cardiorespiratory ability affects the metabolism of fatty acids and liver TG (Romijn \& Pijl, 2009).

Statins are widely used for the treatment of dyslipidemia, as they also cause multiple pleiotropic beneficial effects (Liao \& Laufs, 2005). However, there are reports of hepatotoxicity associated with the use of statins, reflecting increased AST and ALT. Asymptomatic elevation of transaminases is rare, observed in $0.5-2 \%$ of patients treated with statins.

The mechanism of hepatotoxicity triggered by statins is not completely clear, though. Some mechanisms are proposed for hepatotoxicity due to the use of statins, such as high energy reaction in the cytochrome P450, impairing calcium homeostasis with the disruption of intracellular fibrils and lysis of hepatocyte. Additionally, immune reactions can occur due to the formation of hypolipidemic metabolites in the liver; hepatotoxicity caused by $\mathrm{T}$ cells with additional inflammation mediated by neutrophils, as well as apoptosis with the destruction of hepatocytes and oxidative stress caused by damage to intracellular organelles (Lee, 2003; Jaeschke et al., 2002).

In this study, the morphometric analysis confirms liver abnormalities associated with simvastatin only with a hypercholesterolemic diet and sedentarism. These animals showed changes in the shape and size of the hepatocytes nuclei, whereas the association with physical exercise shows morphological similarities with the control groups. This suggests that the presence of hypercholesterolemic diet together with sedentarism may have been the cause of morphometric changes of hepatocytes in this animal model. The study of changes in cell volume is very important because this data, in normal conditions, shows constant in different cell types, regardless of organism size. Thus, the mass of an organ depends on the number of cells rather than on their volume. It is also known that nuclear volume changes reflect the functional state of the cells. When the cells present full physiological activity, the nuclear volume is larger compared with that observed in state of rest. This is probably due to the changes caused by the synthesis of DNA, RNA and/or proteins related with cell maintenance process (Santos \& Azoubel, 1996; Ferreira et al., 1994). In short, the nuclear changes detected in this study could be attributed to inadequate synthesis, by action of DNA, RNA and/or proteins which maintains a normal cellular process.

As a conclusion, commercial food diet, with or without physical activity, does not alter the size and shape of the hepatocytes nuclei; the hypercholesterolemic diet combined with sedentarism influences the changes in morphometric parameters of hepatocytes; and the association of simvastatin and exercise seems to protect the hepatocytes nuclei compared to hypercholesterolemic diet in animal model with dyslipidemia.

ACCIOLY, M. F.; SOUZA, D. R. S.; PADULLA, S. A. T.; CAMARGO FILHO, J. C. S.; DO CARMO, E. M. ; MARTINS, A. T.; BRANDÃO, A. C. \& AZOUBEL, R. Efecto de las estatinas y ejercicio físico aeróbico sobre la función hepática en ratas dislipémicas - Estudio morfométrico. Int. J. Morphol., 31(4):1309$1316,2013$.

RESUMEN: El presente estudio se realizó con la finalidad de evaluar el efecto de las estatinas asociadas con el ejercicio físico (PE) en las células del hígado, en ratas con dislipidemia a través de cariometría. Los animales fueron divididos en seis grupos: animales sometidos a una dieta hipocolesterolemiante (HD), simvastatina, con (G1) y sin (G2) ejercicio físico (PE); HD enviado (G3) o no (G4) para educación física y dieta comercial (F) con (G5) y sin (G6) PE. El análisis histológico del hígado se realizó por tinción de los portaobjetos con hematoxilina y eosina. El estudio cariométrico incluyó la medición de los diámetros mayor y 
menor de los núcleos de hepatocitos. Se realizó la prueba de Shapiro-Wilk. Para determinar las diferencias entre los grupos, se realizó la prueba de Kruskal-Wallis con Dunn. El nivel de significación se fijó en $5 \%$. No se encontraron diferencias en los núcleos de hepatocitos entre G5 y G6. Los núcleos fueron observados cuando estos grupos estaban relacionados con G3 y G4. No hubo diferencia entre G1 y G6. La comparación entre G6 y G2 mostró que los núcleos en G2 eran más pequeñas. No se detectaron diferencias entre el G5 y G1. Se observaron cambios en la forma núcleos en G2 en comparación con G1. Considerando G2 y G3, se observó en G3 una disminución en el tamaño de los núcleos. En el análisis comparativo con G4, G2 mostró cambios en la forma . El tamaño y forma de los núcleos G1 eran más grandes que G3, así como cambios en la forma se observaron cuando se compararó con G4. G4 mostraron núcleos menores que G3. Por tanto, F, asociados o no a la práctica de PE, no altera el tamaño y la forma de los núcleos de hepatocitos; HD combinada con influencias sedentarismo cambios en los parámetros morfométricos de los hepatocitos, y la asociación de simvastatina y PE parece proteger a los hepatocitos con respecto a la HD.

\section{Cariometría.}

PALABRAS CLAVE: Simvastatina; Ejercicio; Dieta;

\section{REFERENCES}

Accioly, M. F.; Camargo Filho, J. C. S.; Padulla, S. A. T.; Lima, A. L. Z; Bonfim, M. R.; Carmo, E. M.; Pinhel, M. A. S.; Lima, M. A.; Azoubel, R.; Brandão, A. C. \& Souza, D. R. S. Efeito do exercício físico e estatinas na Função muscular em animais com dislipidemia. Rev. Bras. Med. Esporte, 18(3):198-202, 2012.

Argo, C. K.; Loria, P.; Caldwell, S. H. \& Lonardo, A. Statins in liver disease: a molehill, an iceberg, or neither? Hepatology, 48(2):662-9, 2008.

Armitage, J. The safety of statins in clinical practice. Lancet, 370(9601):1781-90, 2007.

Beltowski, J; Wójcicka, G. \& Jamroz-Wisniewska, A. Adverse effects of statins - mechanisms and consequences. Curr. Drug Saf., 4(3):209-28, 2009.

Bernardes, D.; Manzoni, M. S. J.; Souza, C. P.; Tenório, N. \& Damaso, A. R. Efeitos da dieta hiperlipídica e do treinamento de natação sobre o metabolismo de recuperação ao exercício em ratos. Rev. Bras. Educ. Fis. Esporte, 18(2):191-200, 2004.

Bucolo, G. \& David, H. Quantitative determination of serum triglycerides by the use of enzymes. Clin. Chem., 19(5):47682,1973

do Valle, V. S.; de Mello, D. B.; Fortes, M. S. R.; Dantas, E. H. M. \& Mattos, M. A. Efeito da Dieta e do Ciclismo Indoor Sobre a Composição Corporal e Nível Sérico Lipídico. Arq. Bras. Cardiol., 95(2):173-8, 2010.
Ferreira, R. R.; Assis, G. F. \& Taga, R. Estudo morfométrico da evolução do volume nuclear e citoplasmático e da relação citoplasma/núcleo de células acinosas de glândulas parótidas do rato durante a vida pós-natal. Rev. Bras. Cienc. Morfol., 11(2):142-8, 1994.

Jaeschke, H.; Gores, G. J.; Cederbaum, A. I.; Hinson, J. A.; Pessayre, D. \& Lemasters, J. J. Mechanisms of hepatotoxicity. Toxicol. Sci., 65(2):166-76, 2002.

Joris, I.; Zand, T.; Nunnari, J. J.; Krolikowski, F. J. \& Majno, G. Studies on the pathogenesis of atherosclerosis. I. Adhesion and emigration of mononuclear cells in the aorta of hypercholesterolemic rats. Am. J. Pathol., 113(3):341-58, 1983.

Kay, S. J. \& Fiatarone Singh, M. A. The influence of physical activity on abdominal fat: a systematic review of the literature. Obes. Rev., 7(2):183-200, 2006.

Kelley, G. A. \& Kelley, K. S. Aerobic Exercise and HDL2-C: A meta-analysis of randomized controlled trials. Atherosclerosis, 184(1):207-15, 2006.

Lee, W. M. Drug-induced hepatotoxicity. N. Engl. J. Med., 349(5):474-85, 2003.

Liao, J. K. \& Laufs, U. Pleiotropic effects of statins. Annu. Rev. Pharmacol. Toxicol., 45:89-118, 2005.

Lira, F. S.; Rosa, J. C.; Lima-Silva, A. E.; Souza, H. A.; Caperuto, E. C.; Seelaender, M. C.; Damaso, A. R.; Oyama, L. M. \& Santos, R. V. Sedentary subjects have higher PAI-1 and lipoproteins levels than highly trained athletes. Diabetol. Metab. Syndr., 2:7, 2010.

Ludwig, J.; McGill, D. B. \& Lindor, K. D. Review: nonalcoholic steatohepatitis. J. Gastroenterol. Hepatol., 12(5):398-403,1997.

Magkos, F. Exercise and fat accumulation in the human liver. Curr. Opin. Lipidol., 21(6):507-17, 2010.

Matos, S. L.; Paula, H.; Pedrosa, M. L.; Santos, R. C.; Oliveira, E. L.; Chianca, Jr. D. A. \& Silva, M. E. Dietary models for inducing hypercholesterolemia in rats. Braz. Arch. Biol. Tech., 48(2):203-9, 2005.

Neves, R. H.; Alencar, A. C. M. B.; Aguila, M. B.; Mandarimde-Lacerda, C. A.; Machado-Silva, J. R. \& Gomes, D. C. Somatic, biochemical and hepatic alterations in wild type mice chronically fed high fat diet. Int. J. Morphol., 24(4):625-32, 2006a.

Neves, R. H.; Alencar, A. C.; Aguila, M. B.; Mandarim-deLacerda, C. A.; Machado-Silva, J. R. \& Gomes, D. C. Hepatic stereology of Schistosomiasis mansoni infectedmice fed a high-fat diet. Mem. Inst. Oswaldo Cruz, 101(Suppl. 1):253-60, 2006 b. 
ACCIOLY, M. F.; SOUZA, D. R. S.; PADUlla, S. A. T.; CAMARGO FILHO, J. C. S.; DO CARMO, E. M. ; MARTINS, A. T.; BRANDÃO, A. C. \& AZOUBEL, R. Effect of Statins and Aerobic Physical Exercise on Liver Function in Dyslipidemic Rats - Morphometric Study. Int. J. Morphol., 31(4):1309-1316, 2013.

Pachaly, J. R. \& Brito, H. F. V. Interspecifc Allometric Scaling. In: Fowler, M. E. \& Cubas, P. R. (Eds.). Biology, Medicine and Surgery of South American Wild Animals. Ames, Iowa University Press, 2001. pp.475-81.

Padulla, A. S. T.; Azoubel, R.; Bonfim, M. R.; Accioly, M. F.; Camargo Filho, J. C. S.; Padovani, J. A.; Brandão. J. C. \& Souza, D. R. S. Effects of statin and aerobic physical exercise association in the cardiomyocites of the rat: morphometric study. Int. J. Morphol., 27(1):83-8, 2009.

Paragh, G. \& Fülöp, P. Impact of lipid lowering therapy on liver function. Orv. Hetil., 150(26):1205-12, 2009.

Pedersen, B. K. The diseasome of physical inactivity--and the role of myokines in muscle--fat cross talk. J. Physiol., 587(Pt. 23):5559-68, 2009.

Reeves, P. G; Nielsen, F. H. \& Fahey, C. G. Jr. AIN-93 purified diets for labocamundongsry rodents:report of the American institute of nutrition ad hoc writing committee on the reformulation of the AIN-76A rodent diet. J. Nutr., 123(11):1939-51, 1993.

Romijn, J. A. \& Pijl, H. The muscle-liver axis: does aerobic fitness induce intrahepatic protection against nonalcoholic fatty liver disease? J. Physiol., 587(Pt. 8):1637, 2009.

Ross, R.; Dagnone, D.; Jones, P. J.; Smith, H.; Paddags, A.; Hudson, R. \& Janssen, I. Reduction in obesity and related comorbid conditions after diet-induced weight loss or exercise-induced weight loss in men. A randomized, controlled trial. Ann. Intern. Med., 133(2):92-103, 2000.

Sala, M. A.; Lopes, R. A. \& Matheus, M. Método morfométrico para análise cuantitativo de los tejidos. Determinación de los parâmetros normales para el hepatócito de rato. Arch. Fac. Med. Zaragoza, 32:2931,1992 .

Santos, H. S. L \& Azoubel, R. Embriologia comparada: texto e atlas. Jaboticabal, FUNEP, 1996.

Sasaki, J. E. \& Santos, M. G. O papel do exercício físico aeróbio sobre a função endotelial e sobre os fatores de risco cardiovasculares. Arq. Bras. Cardiol., 87(5):e22733, 2006.

Tavintharan, S.; Ong, C. N.; Jeyaseelan, K.; Sivakumar M.; Lim, S. C. \& Sum, C. F. Reduced mitochondrial coenzyme Q10 levels in HepG2 cells treated with highdose simvastatin: a possible role in statininduced hepatotoxicity? Toxicol. Appl. Pharmacol., 223(2):1739, 2007.

\author{
Correspondence to: \\ Marilita Falângola Accioly \\ Av. Frei Paulino, 159, sala 331 \\ Bairro Nossa Senhora da Abadia. \\ ZIP code: $38025-180$ \\ Uberaba/MG \\ Brazil
}

Email: marilita@terra.com.br

Received: 16-04-2013

Accepted: 03-08-2013 